Joanna Szymczak

https://doi.org/10.26881/pwe.2020.48.04

ORCID: 0000-0002-5755-5790

Uniwersytet Kazimierza Wielkiego

joannaszymczak1@gmail.com

\title{
Zabawa narracyjna jako strategia sprzyjająca autentycznemu uczeniu się dzieci
}

\section{Summary}

A narrative play as a strategy supporting authentic learning by children

A narrative play is a strategy which was used while creating educational situations for children aged 6 to 9, in the Narrative Environments for Play and Learning research project. The process of building the strategy and implementing it in practice was monitored in order to answer the question of the strategy's meaning for creating a teaching environment. The observation of children and teachers, the interviews with teachers and the analysis of the collected empirical material in the form of audio and video recordings lead to a conclusion that a narrative play supports developing self-regulation in students (see: Arends 1994: 488-499; Filipiak 2012: 70-79). Some specific properties and the role of a teacher who is a facilitator genuinely engaged in its construction are characteristic qualities of a narrative play. It supports developing reflectiveness and reflection regarding such aspects as: educational problems, motives of one's behavior, one's own beliefs.

Keywords: narrative play, self-regulation, reflectiveness, reflection, teacher's and student's genuine engagement

Słowa kluczowe: zabawa narracyjna, samoregulacja, refleksyjność, refleksja, autentyczne zaangażowanie dziecka i nauczyciela

\section{Wstęp}

Kreowanie sytuacji edukacyjnych sprzyjających osiąganiu przez dzieci zadań rozwojowych, tworzenie przestrzeni kulturowej pozwalającej każdemu uczniowi rozwijać jego umiejętności i zdolności to cele nauczyciela, któremu bliskie jest towarzyszenie dziecku w konstruowaniu siebie jako podmiotu coraz bardziej niezależnego od innych. Próby budowania określonych propozycji pracy nauczyciela z dziećmi podjęto w projekcie Narrative Environments for Play and Learning (NEPL) w obszarze wczesnej edukacji. To na tym etapie dzieci tworzą fundamenty dla dalszego funkcjonowania w szkole i poza jej murami (zob. szerzej: Klus-Stańska, Nowicka 2005; Brédikytė 2012: 104). Efektem działalności zespołów badaczy i nauczycieli jest model projektowania zabawy narracyjnej, w której współuczestniczą dzieci i dorośli, odgrywając określone role. 


\section{(Za)rys projektu NEPL}

Międzynarodowy projekt NEPL realizowano w latach 2015-2017 w ramach programu Erasmus+ KA2 STRATEGIC PARTNERSHIP PROJECT n 2015-1-LT01-KA201-013443 w czterech krajach: w Finlandii, Polsce, Wielkiej Brytanii i na Litwie. Jego koordynatorem był zespół badaczy z Lithuanian University of Educational Sciences z Wilna. Kierownikiem zespołu polskich badaczy była prof. dr hab. Ewa Filipiak z Wydziału Pedagogiki Uniwersytetu Kazimierza Wielkiego w Bydgoszczy. Głównym celem projektu było zbudowanie takiego modelu pracy nauczyciela z dzieckiem, który wspiera rozwój jego samoregulacji. Ramę teoretyczną dla myślenia o zabawie, uczeniu się dziecka i roli dorosłego w projektowaniu środowiska uczenia się badacze zbudowali, korzystając z kulturowo-historycznej koncepcji Lwa S. Wygotskiego w interpretacji Ewy Filipiak (2008; 2011; 2012; 2015a; 2015 b; 2015c), natomiast teoretycznym wsparciem w dochodzeniu do rozumienia istoty zabawy narracyjnej było podejście Penttiego Hakkarainena (2015) oraz Mildy Bredikyte i Agne Brandisauskiene (2015). W projekcie - wraz z badaczami - uczestniczyli nauczyciele edukacji przedszkolnej i wczesnej edukacji (zob. szerzej: Hakkarainen i in. 2017).

Zespół polskich badaczy, jako jedyny, współpracował z dwoma nauczycielami wczesnej edukacji: wychowawcą klasy I i z wychowawcą klasy III szkoły podstawowej. Zadaniem nauczycieli było po pierwsze zrozumienie tego, na czym polega projektowanie środowiska uczenia się w koncepcji Wygotskiego, a po drugie aktywny udział w tworzeniu zabawy narracyjnej. W realizacji tych zadań wspierali ich badacze. Dzięki wspólnemu zaangażowaniu całego zespołu projektowego zostały zidentyfikowane problemy edukacyjne, których dotyczyła zabawa narracyjna. Uczestnicy projektu dokonali tego na podstawie obserwacji funkcjonowania dzieci w codzienności szkolnej i wywiadu z wychowawcami na temat potrzeb, zainteresowań i trudności spostrzeganych w ich zespołach klasowych. Działalność polskich uczniów była związana z trzema głównymi zagadnieniami: bezdomność, tożsamość i pomaganie innym. Istotnym etapem wspólnych przygotowań do korzystania z tej strategii było znalezienie „dobrej” książki, której epizody inspirowały do zbudowania ramy dla zabawy narracyjnej. Polski zespół skorzystał z propozycji Beatrice Alemagny (2015). Tworzenie szkicu tej metody było zasadniczym, procesualnym zadaniem badaczy i nauczycieli, realizowanym równolegle z gromadzeniem materiału empirycznego, który następnie został poddany analizie. Składały się na niego noty z obserwacji pracy dzieci i nauczycieli, wywiady z nauczycielami, a także nagrania audio i wideo ${ }^{1}$.

\section{Zabawa narracyjna jako przestrzeń kulturowa dla doświadczania i przeżywania}

Uczniowie mają potrzebę rozumienia istoty działań, które wykonują. W sytuacji, w której nie otrzymują informacji dotyczącej celu podejmowanych poczynań, samodzielnie nadają im sens (Wood 2006: 70-73; Hakkarainen, 2015: 77). W zabawie narracyjnej pojawiały

1 Zgromadzony materiał empiryczny znajduje się w Laboratorium Zmiany Edukacyjnej - Centrum Badań nad Uczeniem się i Rozwojem Uniwersytetu Kazimierza Wielkiego w Bydgoszczy. 
się przestrzenie dla stawiania dzieci w obliczu ważnego dla nich zadania. Te pola tworzył bohater zabawy. To on przeżywał określone przygody, doświadczał trudności i miał wątpliwości. $Z$ tego powodu prosił uczniów o pomoc w podjęciu decyzji. Zespół badaczy i nauczycieli skonstruował zadanie problemowe, uwzględniając ich potrzeby, możliwości oraz zadania rozwojowe (por. Hakkarainen i in. 2017). Autentyczność, niedookreśloność, istotność zagadnienia dla dzieci, złożoność, zespołowość projektowanej sytuacji problemowej (Arends 1994: 383) motywowały je do podejmowania działań, poszukiwania i uwzględniania różnorodnych aspektów, oceniania proponowanych rozwiązań, antycypowania prawdopodobnych konsekwencji. Nauczyciel kreował przestrzeń kulturowa, aby uczniowie udzielili sobie odpowiedzi na pytanie o powód angażowania się w wykonanie określonego zadania. Kluczową rolę odegrały dwa aspekty rozwojowe charakterystyczne dla uczniów na tym etapie. Należały do nich: 1) doświadczanie poczucia sensu podejmowanych działań i 2) zdolność nadawania wagi podejmowanej czynności. Stawianie przed dzieckiem zadań adekwatnych do jego potrzeb edukacyjnych pozwalało mu nadawać znaczenie własnemu wysiłkowi.

Zabawa narracyjna wspomagała rozwój „świata wewnętrznego” ucznia (Hakkarainen 2015: 78). Dzięki niej dziecko rozwijało zdolność rozumienia i kontrolowania własnych emocji, a także umiejętność reagowania adekwatnie do danej sytuacji. Doświadczało ono tego, że nie zawsze ma możliwość działania zgodnie wyłącznie z indywidualnymi potrzebami i motywami. Uświadamiało sobie, jakie znaczenie dla jego poczynań ma kontekst sytuacyjny, m.in.: obecność innych osób, ich potrzeby i możliwości, dobro wspólne, dostępne środki (por. Gray 2013).

Strategia ta stworzyła uczniowi przestrzeń kulturowa dla konstruowania roli bohatera, a także dla doświadczania siebie ,,innym” od tego, którym był na co dzień. Sprzyjała budowaniu - na poziomie wyobrażeniowym - konstruktu własnej osoby (Brèdikytè 2012: 104), a w konsekwencji motywowała dziecko do zmieniania siebie (por. Hakkarainen 2015: 94; Hakkarainen i in. 2017: 15).

W opisywanej metodzie znaczącą rolę odgrywały „formy idealne”, czyli postaci występujące w zabawie (Hakkarainen 2015: 94). Dzięki przeżywanym przygodom, problemom, trudnościom dzieci angażowały się w świat zabawy i kreowały rolę. W tej rzeczywistości uczniowie doświadczali poczucia bezpieczeństwa, a ono z kolei motywowało ich do podejmowania różnorodnych, niczym nieograniczonych (w świecie zabawy wszystko jest możliwe) działan. Aktywność dzieci była związana z zadaniem, którego wykonania się podjęły. Ono natomiast dotyczyło kłopotu, z którym borykał się bohater (por. Hakkarainen 2015: 94; Hakkarainen i in. 2017). Uczniowie wspierali „formę idealną" w jej zmaganiach z problemem. Przeżywała ona dylemat, a dzieci pomagały jej w podjęciu określonej decyzji. Analizowały one sytuację bohatera, stawiały hipotezy, wspólnie z rówieśnikami je weryfikowały, a w konsekwencji wybierały dane rozwiązanie. W procesie dochodzenia do niego doświadczały różnicy zdań i poglądów, złożoności określonego fragmentu rzeczywistości, wielości aspektów znaczących dla danej sytuacji i wymagających ich uwzględnienia. Dzięki temu dzieci miały możliwość rozwijania: 
poczucia odpowiedzialności (każda decyzja była związana z określonymi konsekwencjami), poczucia sprawstwa (propozycja każdego ucznia była godna uwagi), kompetencji społecznych, umiejętności współdziałania (por. Gray 2013; Hakkarainen i in. 2017: 14).

Dla jakości narracji znaczenie miał sposób prezentowania „form idealnych” i stopień ich atrakcyjności dla uczniów. Bohaterowie stanowili punkt odniesienia w zakresie wartości czy też zachowań, które miały ugruntowanie kulturowe (Hakkarainen 2015: 83). Spotykanie się w zabawie narracyjnej różniących się od siebie „form idealnych” stworzyło dzieciom przestrzeń kulturowa dla przeżywania konfliktu moralnego. Zachęciło je do namysłu nad istotą ,,dobra” $i$,zła”, a także nad tym, jakie znaczenie dla oceniania działań własnych i innych ludzi miał kontekst sytuacyjny. Pozwoliło im również doświadczać trudności związanych z uznawaniem danych czynów za jednoznacznie „dobre” czy też „złe”. „Formy idealne” nie muszą prezentować wyłącznie pożądanych wzorców. Można mówić o ideałach pozytywnych oraz negatywnych (Hakkarainen 2015: 94). Te pierwsze charakteryzują się cechami akceptowanymi, zgodnymi z oczekiwaniami społecznymi. Te drugie natomiast prezentują postawy i zachowania spostrzegane w danej kulturze jako niegodne naśladowania.

Strategia ta stworzyła przestrzeń, w której działania niemożliwe w świecie realnym miały status prawdopodobnych. Uczniowie doświadczali niczym nieograniczonej możliwości manipulowania rzeczywistością w umyśle. Niemniej mieli potrzebę ustalenia, a następnie respektowania zasad adekwatnych do określonej sytuacji. Chcieli wiedzieć, które ich działania będą akceptowane, a które spotkają się z negatywną informacją zwrotną ze strony pozostałych uczestników zabawy (por. Hakkarainen 2015: 95). Zabawa narracyjna zbudowała przestrzeń kulturowa, w której uczniowie doświadczali braku możliwości funkcjonowania w świecie pozbawionym jakichkolwiek reguł. To, co dzieci często spostrzegają jako atrakcyjne w świecie rzeczywistym, straciło moc atrakcyjności w świecie nierealnym. Doszły one do tego, że wspólnie z innymi funkcjonowanie w danej przestrzeni i sytuacji wymagało istnienia pewnych warunków, a także ich uwzględniania we własnych działaniach (zob. Bredikytè 2012: 105; Gray 2013: 193-194).

Opisywana metoda umożliwiła nauczycielowi towarzyszenie uczniom $w$ ich działalności (Hakkarainen 2015: 95). Zabawa narracyjna sprzyjała osiąganiu przez nich zadań rozwojowych. Za jej pośrednictwem dzieci uczyły się, rozwijały różnorodne umiejętności, dochodziły do wiedzy (por. Hakkarainen 2015: 97; Hakkarainen i in. 2017). Postawione w sytuacji problemowej poszukiwały rozwiązań i je tworzyły. Ze względu na to, że pracowały w zespole, kreowały naturalne sytuacje, w których przedstawiały własne pomysły, argumentowały, negocjowały, uzasadniały wybrane rozwiązania.

Ten sposób pracy z dziećmi charakteryzowała „logika narracyjna”. Przejawiała się ona w konsekwentnym konstruowaniu fabuły. Aktywność uczniów była rezultatem doświadczania przez nich tego, jakie znaczenie dla nich i dla innych miał określony problem. W czasie zabawy dzieci poddawały życie codzienne interpretacji, w której podstawowe tworzywo stanowiły symbole. To dzięki nim nadawały one znaczenie codzienności (zob. Hakkarainen 2015: 98). Za ich pośrednictwem to, co zwyczajne w zabawie, odgrywało 
rolę odmienną od tej, którą miało w rzeczywistości². Uczniowie autentycznie zaangażowani w zabawę narracyjną odgrywali określone role, nadawali znaczenia danym obiektom, pomagali bohaterom w rozwiązywaniu problemów. Ponadto analizowali trudności z wielu perspektyw, doświadczali różnorodności punktów widzenia dotyczących tych samych sytuacji, przyjmowali pewne stanowisko, podejmowali decyzje i antycypowali ich konsekwencje. Wszystkie te doświadczenia były przez nich budowane w dającym im poczucie bezpieczeństwa, wyimaginowanym świecie.

Proces zabawy był jednocześnie najistotniejszym jej celem i rezultatem (por. Gray 2013). Zabawa narracyjna jest pozbawiona celów zewnętrznych (Moyles 1989; Garvey 1990; Sutton-Smith 1997; Elkonin 2005; Mihailenko, Korotkova 2001, za: Hakkarainen 2015: 98). Trudno było wygospodarować w niej przestrzeń dla precyzyjnie sformułowanych intencji. Niemniej nauczyciel, który korzystał z tej strategii, zastanawiał się nad tym, do czego mogą dążyć jego uczniowie, tj. z jakimi problemami będą się zmagać; jaką wiedzę będą mogli budować; jakie umiejętności będą mieli szansę rozwijać. Aranżowanie przez nauczyciela tego rodzaju zabawy nie było konsekwencją przypadku, ale efektem zespołowej, pogłębionej refleksji nad tym, co i z jakiego powodu zaproponuje on uczniom. Dzieci nie były informowane przed udziałem w zabawie o tym, jakie cele mają osiągnąć. Po prostu zostały zaproszone do aktywnego uczestniczenia w danej sytuacji. Nie oznacza to jednak, że zabawa narracyjna niczemu nie służyła. Jej przebieg był trudny (niemożliwy?) do przewidzenia (Hakkarainen i in. 2017), opierał się na wzajemnych działaniach podejmowanych przez wszystkich uczestników, stanowiących rezultat dokonywanych $n a$ bieżąco interpretacji (zob. szerzej: Blumer 2007). Żaden z uczestników nie był w stanie przewidzieć, co wydarzy się za chwilę, ponieważ zawsze dostępnych było co najmniej kilka możliwości. Dynamika zabawy i jej kierunek zależały od tego, jak wszystkie zaangażowane w nią osoby zrozumiały sytuację i jakie podjęły czynności. Nauczyciel i bliski mu sposób spostrzegania oraz rozumienia danego fragmentu rzeczywistości nie determinował przebiegu zabawy narracyjnej. Odczuwana przez uczniów potrzeba odnalezienia się w sytuacji zabawy motywowała ich do interpretowania i odpowiadania na działania innych (Blumer 2007; Hakkarainen 2015: 98).

W zabawie narracyjnej uczniowie doświadczali sytuacji problemowej. To oni zidentyfikowali trudność, poddali ją analizie, stworzyli rozwiązanie i podzielili się nim z bohaterem (por. Dewey 1988). Podejmowanemu przez nich działaniu towarzyszyły emocje i rodziła się w nich naturalna potrzeba radzenia sobie z nimi. Ponadto zabawa ta pozwoliła dzieciom odkrywać wartości i budować relacje społeczne (zob. Hakkarainen 2015: 101), rozwijała ich motywację wewnętrzną. Stworzyła przestrzeń kulturowa, w której one indywidualnie i/lub w zespole dochodziły do zrozumienia określonego zagadnienia. W tym procesie korzystały z własnych zdolności, a dzięki temu odkrywały ich znaczenie dla uczenia się. W zabawie narracyjnej uczniowie autentycznie przeżywali problem $\mathrm{i}$ angażowali się w jego rozwiązywanie (por. Bruner 1964: 52-53). Działo się tak dzięki temu,

2 Por. modele interpretacji rzeczywistości doświadczanej w zabawie wyodrębnione przez Gunillę Lindqvist (za: Hakkarainen 2015: 98). 
że weszli oni „(...) w stan nierównowagi (...)” (Wood 2006: 51), który był konsekwencją doświadczania sytuacji wystawiającej na próbę przyjmowane przez nich dotąd założenia. Dzieci doznały „(...) zmieszania wynikającego z zakwestionowania przez zaistniałe realia początkowych wytycznych" (Wood 2006: 51). Ze względu na to, że ten stan umysłu był dla nich „(...) nie do zniesienia (...)” (Wood 2006: 51), motywował je do myślenia, a także działania. Dzięki własnej aktywności stworzyły one określone rozwiązanie/rozwiązania, czyli odkryły „(...) bardziej ogólną ideę czy schemat umysłowy, który doprowadzi do przywrócenia równowagi" (Wood 2006: 51).

Punktem zwrotnym w rozwoju „orientacji znaczeniowej”3 zabawy była „samoinicjacja". To dzięki niej dzieci podejmowały w zabawie autentyczną i autonomiczną działalność. W trakcie jej budowania ich rozwój był stymulowany w największym stopniu. Tworzyły one w pełni samodzielnie (ale nie w samotności) relacje pomiędzy rolami, uwzględniały potrzeby i oczekiwania innych uczestników sytuacji edukacyjnej. To dzieci kreowały dalszy przebieg zabawy i tym samym tworzyły przestrzeń kulturo$w q$ dla analizowania relacji społecznych, co z kolei stymulowało ich rozwój moralny (Hakkarainen 2015: 103-104). „Samoinicjacja” była momentem, w którym uczniowie zapominali o tym, że brali udział w zabawie narracyjnej. Identyfikowali się z sytuacją, w której uczestniczyli, i z działaniami, które podejmowali. Stanowiła ona etap w zabawie, który charakteryzowała refleksja dzieci w odniesieniu do tego, co w danej chwili pozostawało w obszarze ich zainteresowań i/lub potrzeb (por. Szymczak 2017: 69-75). Zabawa narracyjna sprzyjała konstruktywnemu rozwiązywaniu przez nie zadań rozwojowych (zob. szerzej: Appelt 2005: 259-301; Kamza 2014).

Jakość zabawy zależała od zaangażowania uczniów i nauczyciela, zdolności spostrzegania przez nich problemów i kreowania sposobów radzenia sobie z nimi, zadań i wspólnego ich rozwiązywania (o roli dorosłego w zabawie z dzieckiem zob. Brèdikyte 2012: $102,114)$. Wymienione aspekty determinowały „orientację znaczeniową”, która z kolei stymulowała rozwój procesów psychicznych u dzieci. O rozwijaniu się uczniów świadczyła ujawniająca się ich zdolność generalizowania wyobrażeń i pojęć, zdolność mentalnego dokonywania przekształceń w sposób, z którego korzystali oni wcześniej w odniesieniu do realnych obiektów (Hakkarainen 2015: 104).

Zabawa narracyjna była przestrzenia kulturowa dla doświadczania przez uczniów: myśli i emocji wyimaginowanych bohaterów, przekraczania codzienności, funkcjonowania w świecie określonych aspiracji, a także heroicznych czynów. Dzięki temu stanowiła ona klucz ,(...) do rozwoju kreatywnej wyobraźni, wolicjonalnej samoregulacji własnych czynów i życia poprzez emocje innych ludzi" (Hakkarainen 2015: 104). Stworzyła każdemu uczestnikowi możliwość doświadczania „podwójnego subiektywizmu” (Kravtsov, Kravtsova 2010, za: Bredikyte, Brandisauskiene 2015: 112). Zarówno uczeń, jak i nauczyciel - w tym samym czasie - przeżywali daną sytuację edukacyjną z perspektywy

3 „Orientacja znaczeniowa” to kreowane, dzięki emocjonalnemu, uwikłanemu w kontekst społeczno-kulturowy doświadczaniu interakcji społecznych, rozumienie stanowiące podstawę podejmowanych decyzji (por. Hakkarainen 2015: 103-104). 
wewnętrznej (brali w niej udział, ją kreowali) i zewnętrznej (obserwowali: zdarzenia, inne zaangażowane osoby, siebie) (Bredikyte, Brandisauskiene 2015: 112). Rozwijali zdolność diagnozowania sytuacji edukacyjnej i budowania adekwatnej do dokonanego przez nich rozpoznania działalności. Podejmując określone czynności, jednocześnie je analizowali. Obserwowali reakcje uczestników i podejmowali kolejne decyzje związane z własnym zachowaniem (por. Blumer 2007). Strategia ta sprzyjała rozwijaniu refleksyjności, w ramach której pojawiała się przestrzeń kulturowa dla refleksji. Jej uczestnicy wchodzili w interakcje nie tylko z innymi zaangażowanymi w nią osobami, ale także ze sobą. Tworzyli siebie jako badaczy nie tylko bliskiej im i współtworzonej przez nich rzeczywistości, ale także samych siebie. Dokonywali wglądu w siebie, we własne myśli, uczucia (por. Brèdikyte 2012: 105).

\section{Zabawa narracyjna jako przestrzeń kulturowa dla refleksyjności i refleksji dotyczącej codzienności szkolnej}

Refleksyjność to zdolność: obserwowania codzienności edukacyjnej, poddawania jej analizie, uwzględniania różnorodnych punktów widzenia/kontekstów, poszukiwania i/lub tworzenia rozwiązań, nadawania im wymiaru praktycznego. Do jej rozwijania jednostka motywowana jest przez zdarzenia, które zachodzą w otaczającej ją rzeczywistości, lub też przez osoby, które tę rzeczywistość wraz z nią współtworzą (Szymczak 2017: 69-75). Refleksja z kolei jest samodzielnie inicjowanym przez osobę wysiłkiem intelektualnym, który pozwala jej dochodzić do zrozumienia procesów toczących się w jej życiu i zająć wobec nich określone stanowisko. Wysiłek ten podejmowany jest przez nią w momencie, gdy odczuwa ona potrzebę zrozumienia własnego działania w danej sytuacji. Refleksja stanowi droge myślowa, dzięki której podążajaca nią jednostka ma szansę odkrywania interesujących ją, istotnych dla niej kwestii, związanych z jej działalnością (Szymczak 2017: 74). Przedstawione rozumienie refleksyjności i refleksji skłania do skonstruowania twierdzenia, że refleksyjność tworzy przestrzeń kulturowa, w której może zaistnieć refleksja (zob. Szymczak 2017: 73).

Zabawa narracyjna motywowała uczestniczących w niej uczniów i nauczyciela do systematycznego analizowania tworzonych zdarzeń i reagowania na nie. Biorące w niej udział osoby nie tylko odpowiadały na to, co działo się w danej chwili, ale także własną odpowiedzią zmuszały pozostałych uczestników do odnoszenia się do ich zachowania. By dziecko czy nauczyciel mieli szansę odpowiedzieć na sytuację adekwatnie do tego, co ją charakteryzowało, musieli obserwować zachodzące wydarzenia i poddać je interpretacji. Reakcje pozostałych uczestników zabawy stanowiły informację zwrotną, dotyczącą zrozumienia określonej sytuacji i adekwatności podjętych czynności. Wspólna z rówieśnikami (i przy wrażliwym monitorowaniu przez nauczyciela) praca nad danym zadaniem wymagała od dziecka uwzględniania ich pomysłów, rozwijała umiejętność prezentowania własnego stanowiska i negocjowania, a także krytycznego odnoszenia się do cudzych i własnych propozycji. Jej uczestnicy świadomie przyjmowali określone 
rozwiązania. Stanowiła strategię, która rozwijała refleksyjność zarówno uczniów, jak i nauczyciela.

Tworzenie zabawy narracyjnej, udział w niej (zarówno z zewnątrz, jak i od wewnątrz), możliwość wnikliwego przygladania się wielu sytuacjom i sobie motywowały uczestników do stawiania pytań skierowanych do siebie, a także do poszukiwania na nie odpowiedzi. Potrzeba obserwowania, analizowania i interpretowania tego, co było kreowane, po to, by się w tym odnaleźć, stwarzała możliwość wcześniej niezaplanowanego wgladania $w$ siebie. W tym sensie zabawa narracyjna kreowała przestrzeń kulturowa dla refleksyjności i refleksji zarówno ucznia, jak i nauczyciela.

\section{Zakończenie}

Zabawa jest formą działalności dziecka, którą podejmuje ono wcześniej niż w wieku przedszkolnym (zob. szerzej: Smykowski 2005: 198-199; Brèdikytė 2012: 106; Gray 2013). Niezwykle ważną rolę w jego rozwoju odgrywa zabawa dramatyczna (na niby), realizowana przez dziecko na etapie przedszkolnym. Pozwala dziecku spełniać pragnienia, których nie jest w stanie zrealizować w tym wieku w inny sposób. Stanowi również przestrzeń stymulowania jego rozwoju społecznego, emocjonalnego, moralnego, umysłowego. Ponadto jest dla niego źródłem satysfakcji (Smykowski 2005: 199) i najważniejszą linią rozwoju (Wygotski 2002: 141, za: Smykowski 2005: 199). Stanowi ona dla dziecka przestrzeń kulturowa dla doświadczania holistycznego i odkrywania przez nie świata (Hakkarainen i in. 2017: 10). Do jej zaistnienia niezbędne są dwa aspekty: „(...) niezaspokojone pragnienia i zdolność oddzielenia pola wizualnego od pola sensu" (Smykowski 2005: 199).

Dziecko nie traci zdolności bawienia się z chwilą pójścia do szkoły (por. Gray 2013: 259). Oznacza to, że zabawa jest sposobem projektowania warunków uczenia się, z którego może korzystać nauczyciel wczesnej edukacji w pracy z uczniami. Ze względu na specyfikę rozwoju dziecka w tym czasie (tj. zadania rozwojowe, indywidualne potrzeby, możliwości, doświadczane trudności) różni się ona od zabawy na niby, realizowanej przez dziecko w wieku przedszkolnym. Rodzajem, który pozwala uwzględniać tę odmienność, jest zabawa narracyjna. Jako strategia pracy z uczniami stanowi ona respektujący ich potrzeby rozwojowe (zob. szerzej: Appelt 2005: 291, 296-300) pomost edukacyjny, po którym - w poczuciu bezpieczeństwa i wolności - przechodzq oni do etapu edukacji wczesnoszkolnej (por. Appelt 2005: 259-260; Gray 2013: 174-176). Zabawa narracyjna uwzględnia ujawniającą się ,postawę pracy”, związaną z wytrwałością w dążeniu do celu i troską o efekt podjętego działania (Appelt 2005: 290-291). Ponadto pozwala dzieciom doświadczać określonych właściwości zabawy, tzn. jest aranżowana przez nauczyciela, który staje się zaangażowanym w jej przebieg towarzyszem uczniów; stawia dzieci wobec problemów, które one wspólnie rozwiązują; kreuje przestrzeń kulturowa dla analizowania sytuacji bohaterów, a także podejmowanych przez jej uczestników decyzji. 
Istnieją określone warunki „dobrej zabawy”. Należą do nich: 1) sytuacja wyobrażona (Wygotski 2003, za: Brèdikytė 2012: 113); 2) odgrywanie ról; 3) zawiązanie akcji (Elkonin 1989, za: Brėdikytė 2012: 113); 4) zdolność zachowywania dystansu do odgrywanych ról i podejmowanych działań; 5) zdolność odróżniania fikcji od rzeczywistości i nieustanne konfrontowanie ich ze sobą oraz 6) gotowość do uniezależniania się od fizycznych ograniczeń środowiska zabawy, czyli miejsc, rekwizytów. Zmiany rozwojowe zachodzące u dziecka w wieku przedszkolnym dzięki zabawie (Smykowski 2005: 200-205) sprawiają, że na etapie edukacji wczesnoszkolnej jest ono gotowe do respektowania wymienionych powyżej okoliczności towarzyszących tej formie, a także ma potrzebę ich przestrzegania. To oznacza, że zabawa proponowana uczniowi w szkole - jeżeli ma stymulować jego rozwój - powinna stawiać go w obliczu pewnych wyzwań (poznawczych, emocjonalnych, społecznych czy moralnych), czyli zadań sytuujących się w jego strefie najbliższego rozwoju (SNR) (zob. szerzej: Filipiak 2002: 135-148; 2008: 17-34; 2011: 16-28; 2012).

Zabawa narracyjna jest strategią pracy z uczniami, która pozwala nauczycielowi tworzyć przestrzeń kulturowa dla osiągania przez nich zadań rozwojowych i zadań edukacyjnych, przy jednoczesnym dokonywaniu wglądu w siebie, a także w określony aspekt codzienności szkolnej. Dzięki niej rozwijają się nie tylko uczniowie, ale także nauczyciel - autentycznie zaangażowany w jej budowanie uczestnik zdarzeń. Wszystkie osoby biorące w niej udział mają szansę kreowania siebie jako coraz bardziej autonomiczne, niezależne od innych współtwórców codzienności szkolnej jednostki. To strategia, która rozwija refleksyjność dzieci i nauczyciela, a także jest przestrzenia kulturowa dla ich refleksji dotyczącej danego problemu edukacyjnego, uczenia się i siebie.

\section{Literatura}

Alemagna B. (2015), Pięciu Nieudanych. Warszawa, Wydawnictwo Dwie Siostry.

Appelt K. (2005), Wiek szkolny. Jak rozpoznać potencjat dziecka? W: A.I. Brzezińska (red.), Psychologiczne portrety człowieka. Praktyczna psychologia rozwojowa. Gdańsk, Gdańskie Wydawnictwo Psychologiczne.

Arends R.I. (1994), Uczymy się nauczać. Warszawa, Wydawnictwa Szkolne i Pedagogiczne.

Blumer H. (2007), Interakcjonizm symboliczny. Kraków, Zakład Wydawniczy Nomos.

Brédikytė M. (2012), Akt kulturowego upośredniania w zabawie dzieci. „Forum Oświatowe”, 2(47), http://forumoswiatowe.pl, 12.11.2019.

Bredikyte M., Brandisauskiene A. (2015), Zabawa i samoregulacja u dzieci w wieku przedszkolnym. W: E. Filipiak (red.), Nauczanie rozwijające we wczesnej edukacji wedtug Lwa S. Wygotskiego. Od teorii do zmiany w praktyce. Bydgoszcz, Agencja ArtStudio.

Bruner J. (2006), Kultura edukacji. Kraków, Universitas.

Bruner J.S. (1964), Proces kształcenia. Warszawa, Państwowe Wydawnictwo Naukowe.

Dewey J. (1988), Jak myślimy? Warszawa, Książka i Wiedza.

Elkonin D.B. (1989), Izbrannye psikhologicheskie trudy [Zebrane pisma psychologiczne]. T. 1. Moscow, Pedagogika. 
Elkonin D.B. (2005), Psychology of play I-II. „Journal of Russian and East European Psychology”, 43.

Filipiak E. (2002), Konteksty rozwoju aktywności językowej dzieci w wieku wczesnoszkolnym. Bydgoszcz, Wydawnictwo Akademii Bydgoskiej im. Kazimierza Wielkiego.

Filipiak E. (2008), Uczenie się w klasie szkolnej w perspektywie socjokulturowej. W: E. Filipiak (red.), Rozwijanie zdolności uczenia się. Wybrane konteksty i problemy. Bydgoszcz, Wydawnictwo Uniwersytetu Kazimierza Wielkiego.

Filipiak E. (2011), Z Wygotskim i Brunerem w tle: Stownik pojęć kluczowych. Bydgoszcz, Wydawnictwo Uniwersytetu Kazimierza Wielkiego.

Filipiak E. (2012), Rozwijanie zdolności uczenia się. Z Wygotskim i Brunerem w tle. Sopot, Gdańskie Wydawnictwo Psychologiczne.

Filipiak E. (2015a), Możliwość rozwijania myślenia teoretycznego u dzieci w wieku wczesnoszkolnym. Podejście Lwa S. Wygotskiego. „Studia Pedagogiczne”, 68.

Filipiak E. (2015b), Budowanie rusztowania dla myślenia i uczenia się dzieci w perspektywie spoteczno-kulturowej teorii Lwa S. Wygotskiego. W: E. Filipiak (red.), Nauczanie rozwijające we wczesnej edukacji wedtug Lwa S. Wygotskiego. Od teorii do zmiany w praktyce. Bydgoszcz, Agencja ArtStudio.

Filipiak E. (2015c), Myślenie i uczenie się dzieci w perspektywie teorii socjokulturowej L.S. Wygotskiego. W: E. Filipiak, E. Lemańska-Lewandowska (red.), Raport tematyczny z realizacji projektu ACK. Model nauczania rozwijającego we wczesnej edukacji wedlug Lwa S. Wygotskiego. Gotowość studentów i nauczycieli. Możliwości aplikacji. Bydgoszcz, Agencja ArtStudio.

Garvey C. (1990), Play. Enlarged ed. Cambridge, MA, Harvard University Press.

Gray P. (2013). Wolne dzieci. Jak zabawa sprawia, że dzieci sa szczęśliwsze, bardziej pewne siebie i lepiej się uczą? Podkowa Leśna, Wydawnictwo MiND.

Hakkarainen P. (2015), Podejście kulturowo-historyczne do rozwoju samoregulacji u dzieci w zabawie i uczeniu się. W: E. Filipiak (red.), Nauczanie rozwijajace we wczesnej edukacji wedtug Lwa S. Wygotskiego. Od teorii do zmiany w praktyce. Bydgoszcz, Agencja ArtStudio.

Hakkarainen P., Bredikyte M., Skeryte-Kazlauskiene M. i in. (2017), Organizacja środowiska narracyjnego i uczenie sie poprzez zabawe dzieci w wieku 3-8 lat. Przewodnik dla nauczycieli przedszkoli i nauczania wczesnoszkolnego. Bydgoszcz, Uniwersytet Kazimierza Wielkiego.

Kamza A. (2014), Rozwój w okresie dzieciństwa i dorastania. Rozwój dziecka. Wczesny wiek szkolny. W: A.I. Brzezińska (red.), Niezbędnik Dobrego Nauczyciela. Seria I, t. 3. Warszawa, Instytut Badań Edukacyjnych.

Klus-Stańska D., Nowicka M. (2005), Sensy i bezsensy edukacji wczesnoszkolnej. Warszawa, Wydawnictwa Szkolne i Pedagogiczne.

Kravtsov G.G., Kravtsova E.E. (2010), Play in L.S. Vygotsky's Nonclassical Psychology. „Journal of Russian and East European Psychology”, 48.

Mihailenko N.Y., Korotkova N.A. (2001), Kak igrat s detmi [How to play with children]. Moscow, Akademiceski Project.

Moyles J.R. (1989), Just playing? The role and status of play in early childhood education. London, Open University Press.

Smykowski B. (2005), Wiek przedszkolny. Jak rozpoznać potencjat dziecka? W: A.I. Brzezińska (red.), Psychologiczne portrety człowieka. Praktyczna psychologia rozwojowa. Gdańsk, Gdańskie Wydawnictwo Psychologiczne.

Sutton-Smith B. (1997), The ambiguity of play. Cambridge, MA, Harvard University Press. 
Szymczak J. (2017), Refleksja nauczycieli wczesnej edukacji dotyczaca pracy z uczniami (w perspektywie badań rekonstrukcyjnych). Studium teoretyczno-metodologiczne. Bydgoszcz, Wydawnictwo Uniwersytetu Kazimierza Wielkiego.

Wood D. (2006), Jak dzieci ucza się i myśla. Społeczne konteksty rozwoju poznawczego. Kraków, Wydawnictwo Uniwersytetu Jagiellońskiego.

Wygotski L.S. (2002). Zabawa i jej rola w rozwoju psychicznym dziecka. W: A. Brzezińska, M. Marchow (red.), Lew S. Wygotski. Wybrane prace psychologiczne. T. 2. Poznań, Zysk i S-ka.

Wygotski L.S. (2003), Psihologia razvitia rebionka. Moscow, EKSMO. 